\title{
Examination of Studies Aimed at Developing Map Skills in Secondary School Students: A Meta-Analysis
}

\author{
Elvan YALÇINKAYA ${ }^{1}$ \\ Erciyes University, Kayseri \\ TURKEY
}

\author{
Ayten KARACA ${ }^{2}$ \\ Niğde Ömer Halisdemir University, Niğde \\ TURKEY
}

${ }^{1}$ Assoc. Prof. Dr. Erciyes University, Faculty of Education, Department of Social Studies Education, Kayseri, TURKEY. elvanykaya [at] erciyes.edu.tr. ORCID: 0000-0003-1838-0411

${ }^{2}$ Corresponding author: PhD Student. Niğde Ömer Halisdemir University, Institute of Educational Sciences, Department of Social Studies Education, Niğde, TURKEY. aytenkaraca51 [at] gmail.com. ORCID: 0000-0003-3723-7063

\begin{abstract}
In this study, it was aimed to determine the effect of map skills studies conducted for secondary school students on students' academic success and to synthesize research findings. For this purpose, the results of the experimental studies were analyzed in the research by meta-analysis method. Studies within the scope of the research were survey with the main keywords such as map, secondary school, map skill, map literacy and obtained from the database of the National Thesis Center of the Council of Higher Education. In the collection of data, the coding form prepared by the researchers in accordance with the inclusion criteria was used. As a result of the literature, 10 studies were reached on the subject, including 7 master's and 3 doctoral theses that meet the inclusion criteria. The studies were analyzed by transferring them to the CMA 3 (Comprehensive Meta-Analysis) program. In the data analysis, standard deviation, arithmetic mean and sample size values were used from the pretest-posttest measurements of the experimental and control group of the related studies. In the study, the effect size was calculated using the random effects model due to the fact that heterogeneity was observed among the studies included in the meta-analysis. The effect size of the study was interpreted according to Thalheimer and Cook (2002), and the effect size of the study was very broad, and the studies covered by the research had a positive effect on improving academic success. The results obtained in the study showed that studies aimed at improving map skills in the teaching process increased student success.
\end{abstract}

\section{Keywords}

Map Skills, Secondary School Students, Academic Achievement, Meta-Analysis

To cite this article: Yalçınkaya, E., Karaca, A.(2021). Examination of studies aimed at developing map skills in secondary school students: a meta-analysis. Review of International Geographical Education (RIGEO), 11(1), 236-261. doi: 10.33403rigeo.841330 
Geography has a multidimensional place that is necessary for life skills and guides people at every stage of their life. Geography is the result of human efforts to make sense of the earth. With the development of this process of understanding, humanity has begun to better understand its relations with the Earth. Geography is defined by the National Geographic Society of the United States (USA) as "a field of study that allows us to find answers to questions about where things related to the world around us are, how and why they get there" (Geography Education Standards Project, 1994, p. 11). Therefore, geography represents a comprehensive field of study that is shaped by the formation of a sense of curiosity about the entire universe, based on the immediate environment, and the embodiment of inquiry and meaning at the final point.

The National Geographic Society of the United States has stated that geography consists of three components that are interrelated and inseparable. These are classified as subjects, skills and perspectives. The subject is the basic point of the decomposition of basic knowledge and the standards of geography. The subject is also the mainstay of geographical skills. Here, geographical skills consist of asking geographical questions, obtaining geographical information, organizing geographical information, analyzing geographical know, and answering geographical questions. These knowledge and skills should also be addressed from two perspectives: spatial and ecological. Learning any component of geography is not equivalent to learning geography. These three components are required to be geographically informed. Components cannot stand alone (Geography Education Standards Project, 1994, p. 32).

When the discipline of geography is evaluated in the dimension of subject, skill and point of view, it can be said that the subject exists in the universe independently of man or partially through human intervention, while man has a full say in the dimension of skill and point of view, which are the second and third components. In some cases, it may be considered necessary to make human touches to the subject, which is the main basis in the geographical sense, in order to continue his living life. At the same time, the subject in a geographical sense is also the point of origin of the sense of curiosity about geography. This process, which begins with necessity and curiosity, acquires a structure that can be used, transformed and interpreted, embodied in the light of scientific stages. This structure comes across as a structure in which skills and different perspectives will be more effective after this stage and guide the process. This structure of geography, which offers a wide field of study, is of a quality that makes it necessary to acquire skills related to it for the continuation of its living life and adaptation. This structure, which forms the basis of the relevant skills through the geographical issue, carries to a very important point the different perspectives that will arise from the interpretation of skills and skills due to the influence of technological developments at the point reached today. In this case, in order to understand the geographical issue, it is necessary to first know the concept of skill.

Skill is described in the Dictionary of the Turkish Language Association as "depending on a person's predisposition and education a job and succeeding as a fitfor-purpose process ability, skill" (https://sozluk.gov.tr/). Smith (2002), skills "usually acquired through training and experience, something good, making it the 
capacity to competently perform certain tasks" (p. 661) defines it as. Skills in educational settings are organized structures that are supported by achievements in educational programs and play an active role in the multifaceted development of the student. Skills belonging to the discipline of geography are organized in the geography-oriented achievements of the relevant curriculum programs as a subject area. Here, the attainments are in a supportive role in the development of geographical skills. "In other words, achievements should not be considered as a aim that needs to be achieved, but as a tool that will be used to provide students with "geographical skills". Otherwise, geography lessons will remain as lessons in which information about the content of achievements is somehow transmitted to students, and the learning-teaching process does not change much" (Artvinli, 2010a, p. 188).

Skills that can be evaluated in all areas and dimensions are generalizable susceptibility throughout life. At the same time, skills also attainment meaning in each field within the framework of the limitations or possibilities of that field. "Geographic skills are central to the distinctive approach to our understanding of the physical and human features and processes of the Earth, while providing the tools and techniques necessary for us to think geographically" (https://www.nationalgeographic.org/geographic-skills/).

Geography seems to be an effective and powerful main element as a determinant of daily decisions and vital activities. The decisions taken, the next steps and the learning of geographical skills for the continuation of everyday life are also important and necessary for human entities and legal entities other than individuals. Therefore, the learning of geographical skills also concerns societies, international relations, states, structures such as public and state policies. The fact that the distribution of geography in physical and human elements is an advantage for some countries and a disadvantage for some countries is of particular importance for each state in the national and international dimensions. Distribution and diversity of resources cause differences in life, such as settlement, population, social life, economic life and political power. In this case, geographical skills force individuals, societies and states to learn skills for a number of reasons, such as being able to read the current situation arising from the geographical structure, to maintain and develop advantageous situations, to make disadvantaged situations livable on a national and international scale. Defines geographical skills that start in school at an early age and shape an entire life and are very important on an individual, national and international scale Bednarz and Bednarz (1995):

"Important skills for geographers and some academics include research techniques, field observations, graphic presentations including graph, chart and table making, quantitative analysis including statistics and modeling, computer techniques, and historical and qualitative analysis. These tools, methods, and techniques are used by geographers to understand spatial aspects of a wide range of problems, processes, and phenomena. Although they are not specific to geography, they become geographical skills when applied by geographers to answer geographic questions" (p. 53).

In this information, it is seen that the use of the basic skills that we need to acquire in disciplines constitutes the skills that are specific to that discipline. Skills covered in the discipline of geography in the Turkish education system, primary and secondary schools $(4,5,6$ and 7 . classes $)$ in the Social Studies course curriculum at the level of secondary education $(9,10,11$ and 12 . classes $)$ are also organized within 
the geography course curriculum at the level. Looking at the state of geographical skills in two different levels and in the curriculum area, it seems that some skills are common. It is worth noting here that these skills are a field-specific interpretation of the basic skills necessary and generalizable for the continuation of a living life. Observation, research, inquiry, detection, tables, graphs and diagrams interpret, use of evidence, such as literacy and analysis skills, and skills that can be used in almost any field in any situation and features are interpreted within the area constitute the new field by winning their skills in geographical perspective. Skills such as geographical observation, geographic inquiry, environmental literacy and map literacy are examples of this situation. In addition, it is seen that the geographic skills, included in the Social Studies Curriculum constitute four of the six skills (change and continuity perception, observation, perception of space, place, time and chronology perception, social participation, empathy) (Aksoy and Akbaba, 2019; Çelikkaya, 2011; Çelikkaya, Yıldırım and Kürümlüoğlu, 2019; Taşkıran, Baş, and Bulut, 2016; Turan, 2018) that are directly specific to the field of social studies. This situation shows the place and importance of geography in the Social Studies course.

Among the geographical skills common when two different levels and curriculum areas are examined together, map-related skills are also seen. These skills include secondary education $(9,10,11$ and 12 . classes $)$ at the level of 'map skills', primary and secondary school (4, 5, 6 and 7. 'map literacy' is also included among the geographical skills. Map skills, which are among the geographical skills and are of vital importance, have been the main focus of this research in the birth of literature surveying and research data. Map skills are frequently encountered, used at every stage of daily life and have a structure that allows you to learn and develop other geographical skills through yourself. Depending on the importance of map skills, Malik (2015, p. 183) it states that students will come across maps every day of life in lifelong education, so social studies teachers should give students basic map reading skills at a basic level. Aksoy and Sönmez (2012, p. 67) emphasizes that individuals must have acquired map skills in social studies class in order to read and understand maps correctly. As a skill that needs to be developed at an early age, map skills require skill acquisition and map literacy with a structure that includes the language of space and the analysis of spatial information and affects and shapes an entire life. In order to attainment skills and become map literate, it is necessary to first define the map, know its structure and the elements that make it up.

By its most general definition, "a map is a drawing obtained by reducing the bird's-eye view of the entire or part of the earth on a certain scale and transferring it to a plane" (Doğanay and Sever, 2011, p. 355). A map has been a concept that can be defined in different shapes or sizes. Although maps are expressed by loading different features and points of view, the definitions have some in common. Features such as the fact that the map contains spatial information, occurs through the measurement process, and transfers the measurement to a plane are common features that exist in almost most definitions. According to another definition, "maps are visual communication tools that show where, how, and how spatial information is found" (Buğdaycl, 2012, p. 7). The most likely situation is that the discipline of geography comes to mind when it comes to maps. "As is known, cartography cannot be considered independent of geography. Because the principle of distribution, 
which gives identity to the science of geography, can only be applied using maps. Therefore, maps and cartography are identified with geography" (Doğanay and Sever, 2011, p. 349).

The expression 'where', which is the question of the principle of distribution, which is one of the principles of geographical thought in a scientific sense, is the same as the expression of curiosity heard about the geographical issue in daily life and reflects the answer to the question by processing it on the map. Reflecting spatial information and physical and human systems on the map requires reading and interpreting it correctly. So maps gave rise to the concept of map literacy, which is defined as a skill for us to understand language. "Map literacy can enable the individual to understand and interpret thoughts, actions, objects, graphics and symbols, creating awareness of lifelong learning, and attainment problem-solving skills with effective learning in developing this awareness" (Duman and Girgin, 2007, p. 185).

"The acquisition of skills required to read maps should begin with children in primary school" (Bathurst, 1961, p. 26). In the world, map reading skills are a skill acquired at an early age. "Map reading skills in Portugal, (presentation of easy maps of Portugal with major cities, basic comparison between different types of settlements (city-town-village) and regions (beach-black-mountain)) primary school 2. it is a skill that begins to be acquired at the grade level. Map skills, primary school in Hungary 2. it is a skill that begins to be acquired at the grade level (understanding the differences in basic topographic shapes between urban and rural, making graphical comparisons between basic forms of topography)" (Nuñez, 2002).

"Map-related concepts in Azerbaijan are included in the curriculum, under the Life Science course from second to fifth grade, and under the geography subject from sixth to eleventh grade" (Safaraliyeva, Al Hosani and Nuñez, 2019, p. 287). "In the United Arab Emirates, students begin to study geographical concepts at the kindergarten level. Some of these geographical concepts focus on map concepts at a very basic and limited level" (UAE Ministry of Education, 2017, p. 18; Ref. Safaraliyeva, Al Hosani \& Nuñez, 2019, p. 291-292). “1. concepts learned in the social studies course in the classroom are taught in more detail at later levels. 2. in class, students recognize the concept of geographic location, define maps, read different geographical events reflected by different geographical data, determine the location of their cities and other geographical events (gulf, sea, lowland, etc.)" (Safaraliyeva, Al Hosani and Nuñez, 2019, p. 292).

In order for individuals to make effective and efficient use of maps for various purposes for military and economic life and in their daily lives, they must have improved map skills or be a good map literate (Koç, Aksoy and Çifçi, 2017). "Map literacy is possible by acquiring map skills to individuals" (Sönmez, 2019, p. 220). Map skills were expressed by researchers (Board, 1978; Brown, 1986; Dijk, Schee, Trimp and Zijpp, 1994; Havelková and Hanus, 2019a; Herrmann and Pickle, 1996; Gerber, 1984; Liebenberg, 1998; McClure, 1992; Muehrcke, 1981; Rautenbach, Coetzee, and Çöltekin, 2016) at different times in various groupings. 
In the grouping of map skills, it was found that some skills are common in the sub-skills that make up the whole. Map reading, map analysis and map interpretation skills are skills common in classifications made by different researchers (Dijk, Schee, Trimp and Zijpp, 1994; Muehrcke, 1981; Havelková and Hanus, 2019a; McClure, 1992). A similar situation was observed in the classification of Rautenbach, Coetzee and Çöltekin (2016) and McClure (1992). Skills such as understanding symbols, direction finding, location and coordinate determination, distance measurement, area calculation, and map or interpretation of information are common skills in researchers' classifications. It can be said that the scaling and classification sub-skills passed in Brown (1986)'s classification of map skills are also similar to those in Rautenbach, Coetzee and Çöltekin (2016) and McClure (1992)'s classification.

As a different classification, Sylvester (1952; Ref. Board, 1978) classified map skills as three sub-skills in the form of regional limitation, which includes spatial comparisons and the ability to interpret in detail with good reasoning, apart from the ability to find directions expressed in other research.

Map skills the literature is examined, McClure (1992)' classification of map skills, geography into the curriculum and different researchers (Aksoy, 2013; Aksoy and Ablak, 2019; Aksoy, Kılıçoğlu and Ablak, 2015; Erol, 2020; İncekara, 2013; İncekara and Kantürk, 2010; Koç, 2013; Sönmez, 2010) also has been the mainstay of their work.

Expressed in Turkish education system in the teaching of geography map skills include: "location on map, select the appropriate map onto the map the purpose of transferring information, by using the map, making calculations, the spatial distribution sensing, to correctly interpret the map, draft create maps. However, the ability to use a sphere and atlas is also included in geographical skills. Ability to use a sphere and atlas is basically a geographical skill acquired in elementary education programs" (MoNE, 2018, p. 13).

Map skills and map literacy, which have been tried to be defined by creating different categories, have been a topic that has been studied for many years and its importance has been stated in different aspects in each study. As far as the field can be reached in the survey, it has been observed that studies on map skills are higher than studies conducted under the name map literacy, and studies studied under the name map literacy are mainly processed. Havelková and Hanus (2019b) stated that in their study, researchers disagreed about which processes fall within the scope of "map skills" and even how to categorize them. "For this reason, this inadequate definition, indicates a high risk of bias, and therefore, the appropriate approach and important studies benefited from a research tool (tools) that you create, even when only methodological but also significantly reduces the overall quality" (Havelková ve Hanus, 2019b, p. 370). Therefore, in the background of the subject, it can be said that the situation of definition and distinction regarding map skill and map literacy cannot attainment clarity. When studies on the subject were examined, it was observed that map skills at all levels were studied in different sizes and with different measurement tools. Map skills at the elementary level (Hirsch and Sandberg, 2013; Kastens and Liben, 2010; Buğdaycl and Selvi, 2018), at the 
secondary school level (Erol, 2020; Sönmez, 2010), at the high school level (Artvinli, 2010b; Demiralp, 2006; Koç, 2008), at the college level (Aksoy, 2019; Koç and Çifçi, 2016; Havelková ve Hanus, 2019a; Erol, 2019; Koç, Aksoy and Çifçi, 2017; Gilmartin and Patton, 1984; Özcan, 2015) all levels and at the same time (Drumheller, 1968; Lee and Bednarz, 2012).

These skills are transferred at the secondary school level social studies as a subject area which is the area on the map when analyzing the studies in geographic, map reading and interpretation (Abbak, 2016; Üzümcü, 2007), teachers' opinions of skills and use maps (Duman, 2011; Cendek, 2015; Gökçe, 2015), the location coordinate and skills (Kuşcu, 2011), scale skills (İnel, 2011), the use of digital maps (Aktürk, 2012) and in the digital environment, which is a reflection of the map, GIS, Google Earth, etc. use of programs (Tabanll, 2014; Ögütveren, 2014) it has been observed that there are studies on this skill in such areas.

The fact that the geographical skills passed in the 2018 teaching programs are very resonant today and the increasing research on this subject undoubtedly also creates the need for comprehensive and systematic research syntheses on this subject. A large number of studies in the field can be an obstacle to accessing the desired information in a short time. In the meantime, researchers may be curious about the results of the effectiveness of the studies on this subject. In order to answer this question, it is sometimes necessary to consider the results of the research in a detailed and broad form in a single study. A study in this form is a preferred approach for researchers because it offers opportunities such as evaluating results, reaching a general and common judgment on results, and determining the course of future research on this issue. At the moment, the metaanalysis method is considered as a method that can be used for this purpose. This research is a meta-analysis of the status of map skills on the effectiveness of secondary school level.

A meta-analysis study on this subject was not found, while research on map skills increased when studying the field. In the literature review of map skills, it was observed that the studies on the subject consisted mainly of articles and thesis studies. It was observed that the articles were concluded with qualitative data, which were mostly realized by taking opinions from teacher candidates, teachers and students, or with quantitative data over single groups, and the theses were concluded in full experimental designs as well as supported by qualitative data. Different studies by different researchers in different fields map skills teaching methods, techniques, materials, including products and digital media have been dealt with, and in this way academic achievement, attitude, level of remembering and motivation on variables such as the effect of these skills was investigated. In this study, which was shaped by the absence of a meta-analysis study on this subject in the field, the thesis studies were focused on the scope of the research in accordance with the nature of meta-analysis. It is believed that the research will be useful in terms of identifying those who have an impact on academic success from thesis studies related to map skills performed through the mentioned methods. The research looked at the level at which the effect was in general, taking into account research that examined the impact on academic success as a whole. For this purpose, the answer to the following question was also sought: 
Yalçnkaya, E., Karaca, A. (2021). Examination of studies aimed at developing map skills in ...

1) What is the impact of research on map skills conducted for secondary school students on the academic success of students?

\section{Methodology}

\section{Research Design}

This research is a meta-analysis method to examine the impact of research on map skills performed for secondary school students on academic success.

"Both experimental and surveying studies are usually conducted with limited participants for practical reasons, and research results are taken into account only in the context of this limitation. Apart from this limitation, whether a large number of research results on the same subject make sense together, how much the research results confirm each other, how much the results can be generalized, which research contributes to the solution are important questions waiting for answers. The answer to these questions can be given by meta-analysis study" (Büyüköztürk, Kılıç Çakmak, Akgün, Karadeniz and Demirel, 2012, p. 222).

"Meta-analysis means analysis of results from different studies to achieve an overall result by combining them, as well as re-analysis of results from a study" (Dinçer, 2014, p. 2).

\section{Data Collection Process}

As part of the research, it is aimed to achieve studies that examine the impact of academic success among the studies conducted on map skills performed for secondary school students in Turkey. For this purpose, a research was conducted on master's and doctoral theses on the subject by entering the National Thesis Center of the Council of Higher Education "social studies", "geography", "secondary school students", "map", "map skills", "map reading", "map literacy" were used as keywords for accessing the studies. Studies were surveyed in English as "social studies", "geography", "secondary school students", "map”, "map skills", "map reading”, "map literacy". In the curriculum, map-related skills at the secondary school level are given under the name map literacy. Map literacy includes the ability to use map skills, comment, and infer from spatial knowledge. In this aspect, map literacy can be said to be the ultimate point of map skills. Map literacy skill is a fairly new skill as a skill that has entered the 2018 curriculum under this name. Therefore, in the field, studies related to the idea that sufficient dissertation work and experimental dissertation work with this name, which will be included in the analysis, cannot yet be achieved, have also been surveyed through map skills, which have been the subject of more research. Turkish and English language keywords for this "direction finding", "location", “coordinate finding”, "using scale”, "distance measurement", and "map interpretation" were used. Keywords related to map skills and map literacy were surveyed by making different matches with the words field to search on the advanced survey tab in the Thesis Center Database and the 'pass in' and 'only as written' marks next to it.

As a result of the survey, a total of 49 theses on the subject were reached. Looking at the distribution of the total theses reached on a year-by-year basis, it was found that they were studied between 2006 and 2019. It is believed that the first theses reached on the relevant subject were found in 2006, related to the change of the curriculum of the Social Studies Course in 2005-2006 and the structuring of the 
program based on skills and acquisition. In 2006, was included in the research as one of the inclusion criteria within the scope of meta-analysis. Another situation was that all theses reached were within the range of the year specified in the inclusion criteria. As the research dealt with studies conducted for secondary school students on map skills without specifying any disciplinary areas, there was no disciplinary limit in the studies that could be reached. As a matter of fact, looking at the total theses reached during the survey, it was seen that several theses were theses studied in areas such as map engineering, computer and instructional technology education and graphic education. Theses of the reached, 11 are doctoral theses and 38 are master's theses. 10 dissertations were included in the meta-analysis by qualifying theses in accordance with the following criteria.

Inclusion criteria. The following criteria were used to determine the master's and doctoral theses included in the meta-analysis study;

1. A study conducted in an experimental or semi-experimental model on the impact of research related to map skills performed for secondary school students on academic success,

2. The thesis to be evaluated within the scope of the research was studied after this year in line with the skills and acquisition-based social studies course curriculum, which was implemented with the radical change it experienced during the 2005-2006 education period under the influence of the constructivist approach,

3. Study group includes secondary school students,

4. The study was carried out in Turkey,

5. Studies to be evaluated within the scope of the research include data suitable for meta-analysis (arithmetic mean, standard deviation, experiment and control group sample),

6. Parametric statistics,

7. Different methods or measurement tools used in measurement measure academic achievement for map skills and map literacy. 


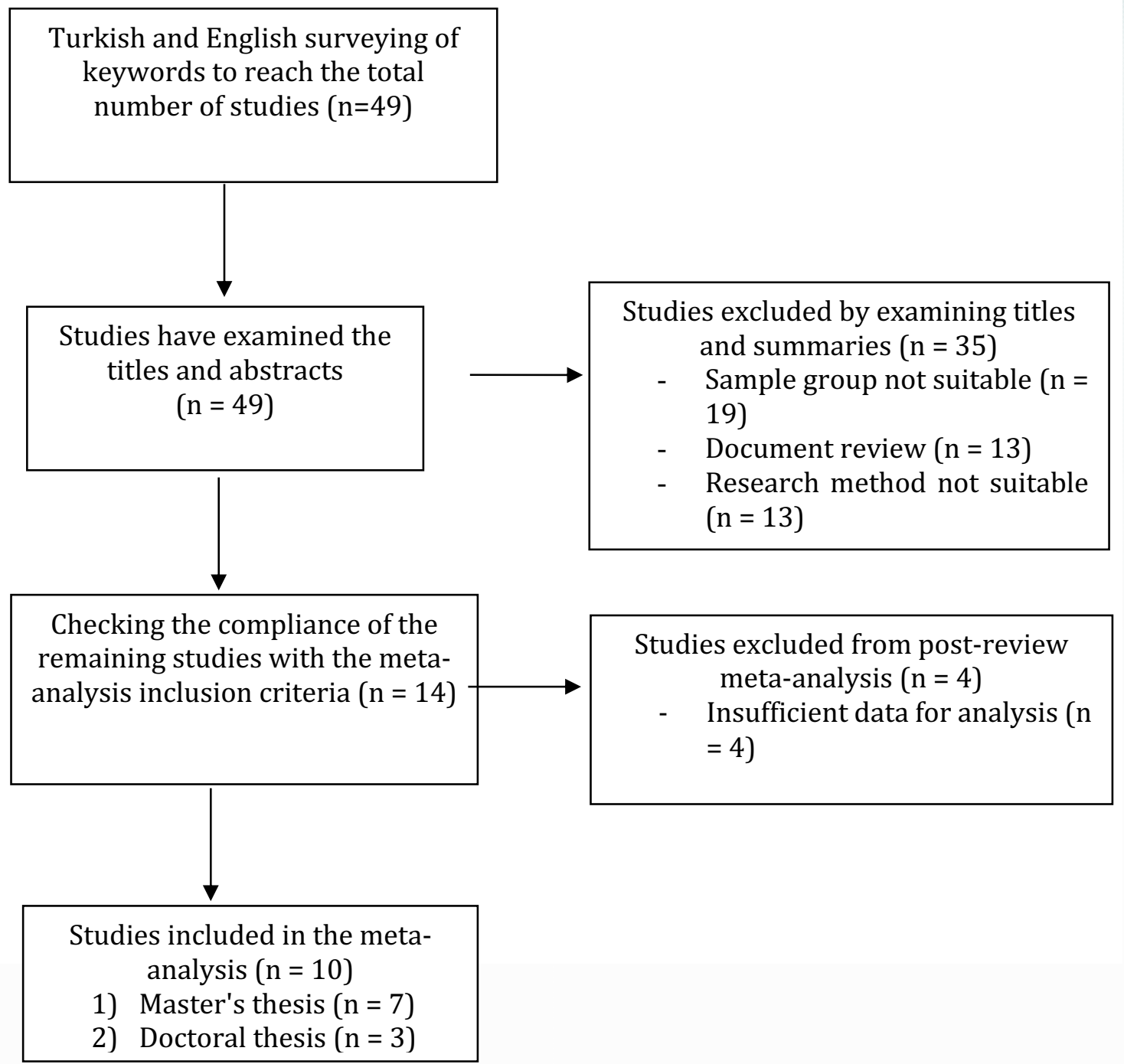

Figure 1. Inclusion Flow Diagram

In the dissertations examined within the scope of the research, it was observed that the effect of map skills on multiple variables at the same time was examined, but due to the lack of a sufficient number of dissertations for meta-analysis in other variables, only the academic achievement variable was focused. Studies achieved within the scope of meta-analysis were based on social studies curriculum area through variables such as stage, subject area and year of study in the process of inclusion in the analysis and were examined accordingly and included in the analysis or excluded from the analysis. For substances containing statistical findings specified in the inclusion criteria, expert opinion was applied.

\section{Data Collection Tools}

Coding form. In the study, a coding form was prepared in order to group the studies accessed, separate them from others, and then easily reach the studies at other stages. This form of study number, author's name, year of study, subject area, a number of teaching positions, sample number, group types, themes (keywords), research methods pre-test of experimental and control group, the weighted average, 
standard deviation, and sample size and post-test experimental and control group the weighted average of the standard deviation and the sample size is reflected.

Data was encoded and compared by two different to ensure encoding reliability. The reliability formula proposed by Miles and Huberman (1994) was used in the reliability calculation. As a result of the reliability = Consensus / (Consensus + Disagreement) calculation, the reliability of the research was calculated as $95 \%$. A general conclusion was reached by taking expert opinion for the $5 \%$ rate, which could not be agreed.

Dependent variable. In this study, the impact of map skills studies on academic success on secondary school students was examined. Accordingly, the calculated effect size is defined as a dependent variable.

"The data collection tools of independent studies conducted by different researchers, the analysis of the data, therefore the measurement results are different from each other. The purpose of the Meta-analysis is to summarize the characteristics and findings of different studies. In order to compare independent studies in this sense, the findings of each study should be expressed as standard scores. In this way, all data is converted into a common metric and the data is merged (Camnalbur, 2008; Ref. Yıldırım, 2015, p. 146)." The values obtained from the studies are converted to standardized effect size, providing equal measurements associated with the standard deviation of each study. A common effect value is obtained by combining separately calculated effect magnitudes for each study" (Ylldırım, 2015, p. 146).

Studies characteristics. "Study characteristics refer to the arguments of metaanalysis. Study characteristics are encoded and used as explanatory variables in data analysis to evaluate relationships between effect magnitudes" (Camnalbur and Erdoğan, 2008; Tarım, 2003; Ref. Kablan, Topan and Erkan, 2013, p. 1632). In the year of publication of the studies, the type of publication and the type of material used in the studies were included in this study as study characteristics. The frequency and percentage values for this are indicated in Table 1.

Table 1

Findings On The Year of Publication Of The Studies, The Type Of Study And The Type Of Material Used In The Study

\begin{tabular}{lll}
\hline Variable & f & $\%$ \\
\hline Year of Publication of the & & \\
Study & 1 & 10 \\
2006 & 5 & 50 \\
2007 & 1 & 10 \\
2011 & 1 & 10 \\
2012 & 1 & 10 \\
2013 & 1 & 10 \\
2019 & 10 & 100 \\
Total & & \\
Type of Study & 7 & 70 \\
Master & 3 & 30 \\
Doctoral & 10 & 100 \\
Total & & \\
Data Collection Tool Used in & & \\
the Study & 10 & 100 \\
Success test & &
\end{tabular}


Instruction supported by 6 digital maps (GIS, Google Earth)

Qualitative tools in data 4

collection (interview,

observation, development

file, lesson plan)

When Table 1 is examined, it is seen that the most relevant studies were given in 2007. It was also seen in the study that the years in which the studies evaluated in the meta-analysis were given according to the inclusion criteria did not progress consecutively. Considering the relevant research on the basis of the type of study, it is seen in the table that there is more master's work as a genre. In addition to the use of computer-based software and methods to express the measurement with qualitative results, it was determined that the success variable was measured by the academic success test, which gave quantitative results. The common aspect of all of these theses, which can create conclusions in meta-analysis, is that they naturally used a success test.

\section{Data Analysis}

In the study, Comprehensive Meta Analysis 3 (CMA) program was used to analyze the data. In addition, the process effect meta-analysis method was used in the analysis of the data.

"Process effect meta-analysis uses standardized effect magnitude denoted by the letter" d "or" g". This term is found by dividing the difference between the averages of experimental and control groups by the total standard deviation (Şahin, 2005; Ref. Yıldirım, 2015, p. 142). This method is used to compare effect sizes by translating independent variable data used in multiple studies into a common unit of measurement" (Yıldız, 2002; Ref. Yıldırım, 2015, p. 142).

In this study, "Hedge's "q"' was used to calculate the effect size and the significance level of the statistical analyses was determined as $95 \%$. Thalheimer and Cook (2002)'s coefficient classification was used to interpret the effect sizes in the study.

- $\quad-0.15-0.15$ trivial level

- $0.15-0.40$ small level

- $0.40-0.75$ intermediate level

- 0.75 - 1.10 wide level

- 1.10 - 1.45 very wide level

- 1.45 - and above excellent level

Thalheimer and Cook (2002)'s coefficient classification, which was used to calculate the average effect size in the study, was also used to interpret the effect size value of each study. Since the effect size values reached for the general and each study in the study are broad in scale, the level classification of Thalheimer and Cook (2002), in which the classification is more detailed, was preferred. 


\section{Findings}

In this section, individual studies examining the impact of map skills studies on academic success conducted for secondary school students in Turkey were combined and evaluated within the scope of meta-analysis. Sample sizes, standard deviations, pre-test and post-test score averages of experimental and control groups were used to calculate effect sizes in the study. Accordingly, the results of the effect size of the studies, the forest graph showing the effect direction of the studies, the effect sizes and homogeneity values according to the fixed and random effects model of the studies, and the publication bias were presented. The 10 theses included in the meta-analysis in this study covered a total of 686 individuals, including 339 (49.41\%) as the number of experimental group samples and 347 (50.59\%) as the number of control group samples.

\section{Findings on Average Effect Size}

Table 2

Comparison of Results of Studies Included In the Meta-Analysis According To Impact Models

\begin{tabular}{|c|c|c|c|c|c|c|c|c|}
\hline \multirow[t]{2}{*}{ Model } & \multirow[t]{2}{*}{$\mathrm{N}$} & \multirow[t]{2}{*}{$\mathrm{Z}$} & \multirow[t]{2}{*}{$\mathrm{P}$} & \multirow[t]{2}{*}{$\begin{array}{l}\text { Total } \\
\text { Heterogeneity } \\
\text { Value (Q) }\end{array}$} & \multirow{2}{*}{$\begin{array}{l}\text { Chi- } \\
\text { Square } \\
\text { Table } \\
\text { Value } \\
(p=0.05)\end{array}$} & \multirow[t]{2}{*}{$\begin{array}{l}\text { Average } \\
\text { Effect Size } \\
\text { (ES) }\end{array}$} & \multicolumn{2}{|c|}{$\begin{array}{l}95 \% \\
\text { Confidence } \\
\text { Interval }\end{array}$} \\
\hline & & & & & & & Low & High \\
\hline Fixed & 10 & 15,029 & 0.000 & & & 1,281 & 1,114 & 1,448 \\
\hline $\begin{array}{l}\text { Effects } \\
\text { Random } \\
\text { Effects }\end{array}$ & 10 & 5,621 & 0.000 & 70,038 & 16,919 & 1,362 & 0,887 & 1,837 \\
\hline
\end{tabular}

In Table 2, the lower limit was 1,114, the upper limit was 1,448, and the average effect size was 1,281 in the $95 \%$ confidence range according to the fixed effects model. This effect size corresponds to the "very wide level" range in the coefficient classification of Thalheimer and Cook (2002). In the calculation of the Z test score for statistical significance, the $\mathrm{z}$ score was found to be 15,029 . It can be said that this result is statistically significant with $p=0.000$. As a result of the homogeneity test, the $Q$ statistical value of the studies included in the analysis was found to be 70,038 . In the chi-square table, the critical value was 16,919 with 9 degrees of freedom at the $95 \%$ significance level. The statistical value of total heterogeneity $Q(70,038)$ calculated in the study was found to exceed the critical value of 16,919 , and thus it was determined that the distribution of effect magnitudes has a heterogeneous structure. In other words, the study found that the distribution of effect sizes dismiss homogeneity.

As a clearer indicator of the degree to which the calculated $Q$ value is heterogeneous, the value $\mathrm{I}^{2}$ (I-squared) was looked at in the study. In the study, the value of $\mathrm{I}^{2}$ increased by $87,150 \%$. Higgins, Thompson, Deeks, and Altman, (2003), defined the value of $\mathrm{I}^{2}$ as "low", "medium", and "high", respectively, over the value of $25 \%, 50 \%$, and $75 \%$. A value of $\mathrm{I}^{2}$ higher than $75 \%$ indicates that the effect size is heterogeneous. It is also understood from this finding that the effect size distribution rejects homogeneity. 
Yalçnkaya, E., Karaca, A. (2021). Examination of studies aimed at developing map skills in ...

When Table 2 was examined according to the random effects model, the lower limit in the $95 \%$ confidence range was 0.887 , the upper limit was 1.837 , and the average effect size was 1,362 . This effect size corresponds to the "very wide level" range in Thalheimer and Cook (2002)'s coefficient classification. In the calculation of the $\mathrm{Z}$ test score for statistical significance, the $\mathrm{z}$ score was found to be 5,621. It can be said that this result is statistically significant with $p=0.000$. Accordingly, it can be said that research on map skills conducted for secondary school students is effective in increasing academic success.

The effect sizes of each of the studies included in the analysis, the lower and upper limits of the $95 \%$ confidence interval, and the effect direction of the studies are given in Figure 2 on the forest plot as follows:

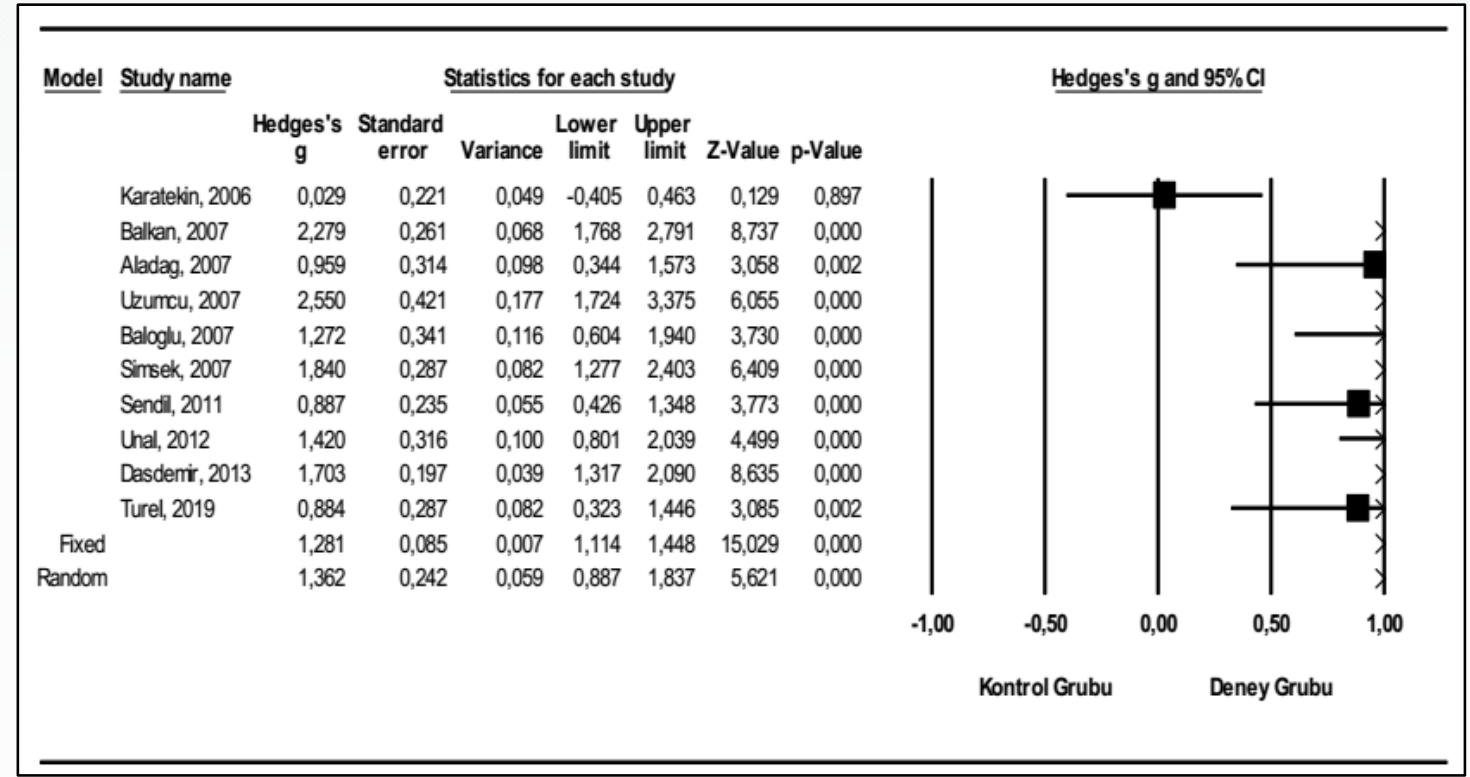

Figure 2. Forest Graph Showing the Direction of Impact of Studies (Forest Plot)

According to figure 2, the effect size value of all 10-thesis studies was positive, and the effect size values in the study varied between 0.029 and 2.550 . Positive effect magnitudes mean a result in favor of experimental groups. In other words, this finding in the study shows that the effect of studies on map skills on academic success is in favor of the experimental group. When the effect size value of each study is examined, it can be said that 4 studies have an excellent effect level (40\%), 3 studies have a wide effect level (30\%), 2 studies have a very wide effect level (20\%), and 1 study behind has a trivial effect level (10\%). The confidence intervals of the studies included in the study range from -0.405 to 3.375 .

\section{Findings on Publication Bias}

"Publication bias is based on the assumption that studies that have not obtained statistically significant results or show a low level of significance will not be published. The fact that such studies have not been published will reduce the reliability of the effect size value obtained as a result of meta-analysis, while also increasing the likelihood of achieving a biased result" (Borenstein, Hedges, Higgins and Rothstein, 2009; Ref. Sezer and İnel, 2017, p. 480).

Funnel plot is a method that is non-statistical and based on visual interpretation. With a subjective assessment looks at the state of publication bias of studies. When 
Figure 3 is examined, the effect sizes on the horizontal ( $\mathrm{x}$ ) axis and the data regarding the standard error value of the research on the vertical (y) axis are included. According to figure 3,10 thesis studies evaluated within the scope of metaanalysis can be said to be partially symmetrically spread on both sides of the vertical line of effect size and positioned close to the combined effect size value in the center of gravity region. "In the publication bias, the funnel chart is expected to be seriously asymmetric. The concentration of research, especially in the lower parts of the funnel, on one side of the line indicating the average effect size (especially on the left side), indicates the possibility of publication bias" (Karadağ, İşci, Öztekin and Anar, 2016, p. 115). Based on this information, it can be said that no evidence was observed in the study of the propagation bias over the funnel scattering graph of the 10 thesis studies included in the meta-analysis. The funnel scattering graph is shown in Figure 3 as follows:

\section{Funnel Plot of Standard Error by Hedges's g}

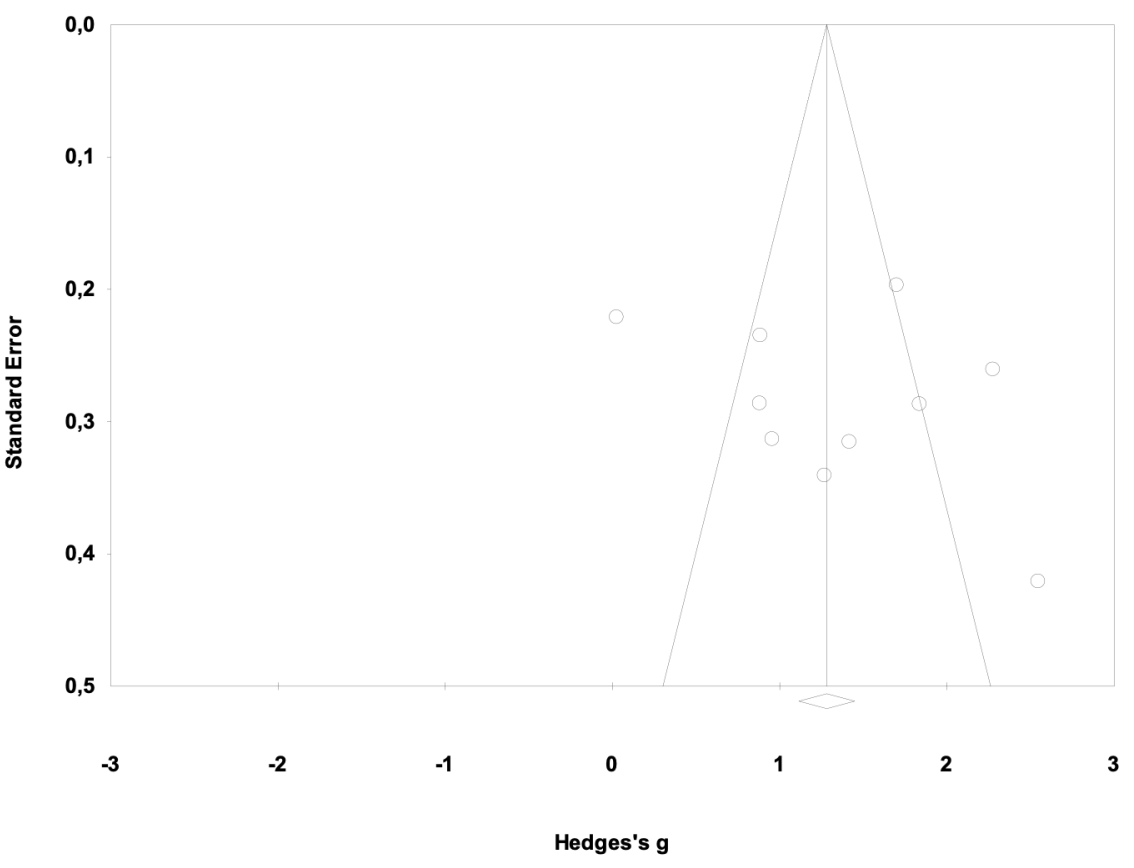

Figure 3. Funnel Plot Graph (Funnel Plot) for the Studies Included in the Meta-Analysis)

In meta-analysis studies, the thought of biased studies included as a negative criticism of the resulting results can be given.

"At the very beginning of the problems encountered in the application of meta-analysis are potential errors and biases caused by a combination of different studies. This problem arises from the fact that independent studies are brought together. The results of meta-analysis can also be wrong when low-quality studies participate in the analysis. In addition, the inclusion or noninclusion of some specific studies in the analysis also affects error and bias" (Çarkungöz and Ediz, 2009, p. 35).

As a result of the analysis, it can be said that the first reason for bias is due to the potential state of error and bias of the research studies. Apart from the studies included in the meta-analysis, studies that cannot be included also appear to affect 
the results of the analysis. "Some data is not published, especially if they give results that are not statistically significant. Thus, non-meaningful data is sent to file drawers" (Rosenthal, 1979). A situation where non-statistically significant studies are left in file drawers and not taken into account in studies is called a file drawer. Some statistical calculations have also been developed by researchers on the effect of bias on the results of the analysis caused by the fact that the studies were not included in the analysis.

"Since a meta-analysis is, by definition, a synthesis of existing literature on a particular topic or variable, the effect of statistical significance testing on the existence of only articles that produce important findings creates a detrimental situation for publication bias. This led Rosenthal to develop the safe $\mathrm{N}$ statistic to determine exactly how many studies would be needed to change meta-analytical results from meaningful to non-meaningful" (Long, 2001, p. 6).

How many more studies are required, obtained by Rosenthal's safe N or fail-safe number statistic, was 593 in this study. This number means that the impact size will decrease to zero when 593 more studies are found. In order for the results of this study, which included 10 studies, to be considered invalid, there are 593 more studies in the field. Since it is not possible to reach another 593 studies that meet the inclusion criteria, or since so many studies have not yet been published, this finding also indicates that there is no publication bias.

Another result of publication bias is the inference-add or crop-fill method of Duval and Tweedie (2000) over effect size. The method is essentially based on the logic behind the funnel graph but offers a more objective approach to interpreting broadcast bias (Duval, 2005; Ref. Tutal, 2019, p. 105). The result of the publication bias for this method is stated in Table 3 as follows.

Table 3

Results of Duval and Tweedie's Trim and Fill Method

\begin{tabular}{|c|c|c|c|c|c|c|c|c|}
\hline & \multicolumn{4}{|c|}{ Fixed Effects Model } & \multicolumn{4}{|c|}{ Random Effects Model } \\
\hline & $\begin{array}{l}\text { Summariz } \\
\text { ed studies } \\
\text { (left) }\end{array}$ & $\begin{array}{l}\text { Point } \\
\text { Estimatio } \\
\mathrm{n}\end{array}$ & Low & High & $\begin{array}{l}\text { Point } \\
\text { Estimatio } \\
\mathrm{n}\end{array}$ & Low & High & $Q$ value \\
\hline $\begin{array}{l}\text { Observe } \\
\text { d Values }\end{array}$ & & 1,28112 & $\begin{array}{l}1,1140 \\
4\end{array}$ & $\begin{array}{l}1,4482 \\
0\end{array}$ & 1,36180 & $\begin{array}{l}0,8869 \\
3\end{array}$ & $\begin{array}{l}1,8366 \\
8\end{array}$ & $\begin{array}{l}70,0377 \\
8\end{array}$ \\
\hline $\begin{array}{l}\text { Adjuste } \\
\text { d Values }\end{array}$ & 1 & 1,22692 & $\begin{array}{l}1,0631 \\
6\end{array}$ & $\begin{array}{l}1,3906 \\
8\end{array}$ & 1,24614 & $\begin{array}{l}0,7720 \\
9\end{array}$ & $\begin{array}{l}1,7201 \\
9\end{array}$ & $\begin{array}{l}80,3077 \\
5\end{array}$ \\
\hline
\end{tabular}

According to the published bias result calculated by this method, symmetry will be achieved by adding 1 study to the left of the funnel graph, and thus the effect size expressed in the random effects model will decrease from 1,361 to 1,246. But it can be said that this reduction cannot change the level of impact. Although the effect size is 1,246 , the effect level is again in a very high-level range when interpreted according to the coefficient classification of Thalheimer and Cook (2002). This finding in the test also indicates that there is no publication bias.

\section{Result and Discussion}


This study was a study in which studies on map skills at the secondary school level were concluded by examining the impact status on academic success by metaanalysis method. In this study, which examined the academic achievement variable, the studies included in the mata-analysis were calculated according to the random effects model and the overall effect size was 1,362. According to the classification of Thalheimer and Cook (2002), this value was found to be in a very wide range of levels (1.10-1.45) in a positive direction. When this value is interpreted according to Lipsey (1990), the level of impact is widely evaluated. "Lipsey (1990) divided effect sizes into three groups. These groups and effect magnitudes are: range 0.00 and 0.32 small; range 0.33 and 0.55 medium; range 0.56 and above wide range" (Shachar and Neumann, 2003, p. 10).

The use of digital maps as a material type in thesis studies on map skills covered within the scope of the study was evaluated as a remarkable and important finding. As a matter of fact, six out of ten thesis studies tested academic success related to map skills in this way. In these studies, Geographic Information System (GIS) and Google Earth programs were used as digital maps. Based on this finding, it can be interpreted that courses supported by computer-based software and materials may be more effective in academic success than the traditional narrative. The fact that students have the opportunity to experience applications and that visual materials are more memorable than what is written or described can be seen as a reason for success. Supporting courses with materials, especially in the teaching of geography subjects, is an important research topic that the result is in favor of students and their academic achievements or in favor of the experimental group. Sezer and Inel (2017), who examined the effect of material use on students' academic success in teaching geography subjects by meta-analysis method, found that material use had a positive impact on academic success at a wide level.

In this study, one of the characteristics of the study and a method used by individual studies to measure academic success, it can be said that the result achieved when evaluating the impact of the material type on the meta-analysis is similar to the study of Sezer and Inel (2017). This situation reached in the study is similar to the study of Kablan, Topan and Erkan (2013), who examined the level of effectiveness of material use in classroom teaching by meta-analysis and found that its impact on academic success was positive and at the highest level. In these studies, it was also seen that computer-aided teaching was used as a material. From this point of view, computer-aided mapping software such as Geographic Information Systems (GIS) and Google Earth can be said to be just as effective as other materials used to measure academic achievement.

In his study, Chang (2002) found that computer-aided teaching increases students' level of knowledge in the cognitive field and can improve their knowledge acquisition skills. Larwin and Larwin (2011) concluded that students' academic achievement increased from $50 \%$ to $73 \%$ when technology was used as part of the curriculum or teaching in their meta-analysis study. In a study in which Kulik and Kulik (1991) reached a conclusion by meta-analysis method over 254 studies, the effect of computer-aided education on success compared to traditional education was investigated and the result was found to be in favor of computer-aided education. Fletcher-Flinn and Gravatt (1995) found that students who received 
computer-aided instruction in their study performed better than $60 \%$ of students who studied in traditional classes.

There are also meta-analysis studies on some teaching methods that are more effective in teaching than the traditional method in the field. Dochy, Segers, Bossche and Gijbels (2003) problem-based learning, Jonhnson, Johnson, and Stanne (2000) cooperative learning methods, Dikmen and Tuncer (2018) computer-based education, Yıldırım, Çırak Kurt and Şen (2019) and of the teaching of learning strategies, Vernon and Blake (1993) problem-based learning, teaching is more effective in the meta-analysis studies are revealed. In this study, the finding of transferring map skills with computer-aided teaching as a type of material is a situation that can take place in the face of traditional teaching. It can be interpreted that the research has reached similar results with the said studies that investigate effectiveness in the face of the traditional method when the type of material used in the study increases success.

The ten studies included in the meta-analysis in the study were examined by year, and the most studies were given in 2007, and experimental studies on the subject did not progress consecutively on a year-by-year basis. On the other hand, the finding that the thesis studies given on this subject are more of a master's thesis study has also been seen in the surveying of the field. In this study, seven of the ten theses covered by meta-analysis constitute master's theses.

A characteristic of research work or moderators of the work, year of publication, type of study (master-doctorate) and the type of material used in the study on the basis of subgroup analyses, meta-analysis, the number of partially included in the study has been made by the researchers because it is rare. Map skills are a skill that exists at all levels. However, in this study, the subject of map skills was limited to the secondary school level. Therefore, in this study, the learning level variable could not be included in the study characteristics because it could not be compared due to this limitation. In other words, it was not possible to look at whether the impact sizes of the studies carried out on map skills differed at the level of primary school, secondary school, high school and university.

In the study, other studies in which computer-aided education is included in the material type variable were looked at on the transfer of map skills with computeraided teaching. Here, different studies have reached similar results. In their study, Sezer and İnel (2017) concluded that the impact sizes of the studies did not differ according to the level of learning variable, that is, the academic success of students increased similarly in teaching geography subjects performed using materials in primary school, secondary school, high school and university. In the same way, Kablan, Topan and Erkan (2013) also found that the effect of the use of materials in classroom teaching in terms of academic success is not differentiated according to the teaching levels. Fletcher-Flinn and Gravatt (1995) also concluded in their study that the impact size did not differ significantly in the learning level variable, and the averages in the levels were quite similar.

During the literature review process of meta-analysis, it can be said that the number was partially small by researchers, given the number of studies conducted on map skills. During the literature review process, it was observed that the studies 
were repeated while searching through different combinations of keywords and words, that is, the same study was frequently encountered. The subject of map skills has a structure that includes more than one skill. The fact that the relevant studies in the sub-skills that make up the map skills are both not included in meta-analysis and in general are not enough affects the number and accessibility of the studies evaluated within the scope of the research. This is also reflected in the variables or subgroup analyses that appear in accordance with the studies included in the research. As a matter of fact, this study also experienced limitations as a result of this situation and could not be entered into variables or subgroup analyses. In the literature review process of meta-analysis, it was found that studies on map skills were carried out by obtaining opinions from the teacher, candidate teacher and student, and it was found that this was more than studies conducted by experimental or weak experimental methods.

Nineteen of the forty-nine theses examined by inclusion criteria in the study cannot be included in the meta-analysis as of the sample group, which can also be considered as an indicator that the studies are small at the secondary school level. This also affects the evaluation or comparison of the result of this study with another meta-analysis. It is believed that this research, conducted on the absence of metaanalysis studies on map skills in the field, can provide data for future studies. The data of this research conducted by meta-analysis tells researchers that research on map skills is in favor of the experimental group in academic achievement, has significant results, should be focused on at the secondary school level and the gap on the subject should be filled in the literature.

\section{Suggestions}

In this study, when the theses examined on the subject and the results obtained within the scope of meta-analysis are interpreted, suggestions can be presented as follows:

- This research can be repeated by looking at the state of the sexes in academic achievement as a sub-variable.

- Social Studies teachers should support their courses with a variety of maps, materials, methods and techniques, including digital maps, in explaining map skills related topics.

- The subject of map skills should be taught in a way that students can relate to their daily lives and immediate environment, and students should internalize skills through practice or activities.

- Based on the finding that map studies in secondary schools should be studied more through digital applications such as Geographic Information System (GIS) and Google Earth, the learning of teachers and students should be supported in this way.

- Based on the fact that research on map skills performed for secondary school students increases academic success, students may be asked to make simple maps and create their own maps for persistence in learning. 
Yalçnkaya, E., Karaca, A. (2021). Examination of studies aimed at developing map skills in ...

- Studies that will be considered at the secondary school level on map skills can be designed with different variables.

\section{References}

Abbak, A. C. (2016). The research of map reading and interpretation skill according to teachers and students views. (Unpublished master thesis). Çukurova University Institute of Social Sciences, Adana. Retrieved from: https://tez.yok.gov.tr

Aksoy, B. \& Ablak, S. (2019). An evaluation of map literacy of social studies preservice teachers. Participatory Educational Research (PER), 6(2), 158-168.

Aksoy, B. \& Akbaba, B. (2019). Skill training in social studies (Introduction). In B. Aksoy, B. Akbaba \& B. Kılcan (Eds.). Skill training in Social Studies. (p. IX- XVII). Ankara: Pegem Akademi.

Aksoy, B. \& Sönmez, Ö. F. (2012). Map skills on images and texts in social sciences course books. Journal of Social Sciences, 12(48), 65-79.

Aksoy, B. (2013). Investigation of mapping skills of pre-service teachers as regards to various parameters. Educational Research and Reviews, 8(4), 134-143.

Aksoy, B. (2019). Determination of map literacy of undergraduate geography students. Review of International Geographical Education Online (RIGEO), 9(3), 591-603. Retrieved from: http://www.rigeo.org/vol9no3/Number3Winter/RIGEO-V9-N36.pdf

Aksoy, B., Kılıçoğlu, G. \& Ablak, S. (2015). The relation of 11-14 years old students map skills and their achievement levels in mathematics. Journal of World of Turks, 7(2). 59-71.

Aktürk, V. (2012). The effects of using animation and digital map for students' capabilities to perceive the space in social studies lesson. (Unpublished master thesis). Afyon Kocatepe Unıversity Institute of Social Sciences, Afyonkarahisar. Retrieved from: https://tez.yok.gov.tr

*Aladağ, E. (2007). The effect of geographic information system (GIS) in teaching social studies to the academic achievements and motivation of 7 th grade students of primary education. (Unpublished doctoral thesis). Gazi University Institute of Educational Sciences, Ankara. Retrieved from: https://tez.yok.gov.tr

Artvinli, E. (2010a). Configuring of geography lessons: Design of a lesson based on action research. Marmara Geographical Journal, 21, 184-218.

Artvinli, E. (2010b). The contribution of Geographic Information Systems (GIS) to geography education and secondary school students' attitudes related to GIS. Educational Sciences: Theory \& Practice, 10(3). 1277-1292.

*Balkan, A. (2007). The effectts of using maps on lesson behaviors, achievement and memorization level in social studies to the seventh grade primary students. (Unpublished master thesis). Sakarya University Institute of Social Sciences, Sakarya. Retrieved from: https://tez.yok.gov.tr

*Baloğlu Uğurlu, N. (2007). The effects on student attitude and achievement to teaching of geographic information systems supported subject of Turkey's natural resources' in social studies courses. (Unpublished doctoral thesis). Gazi University Institute of Educational Sciences, Ankara. Retrieved from: https://tez.yok.gov.tr

Bathurst, L. H. (1961). Developing map reading skills. Journal of Geography, 60(1), 26-32. DOI: $10.1080 / 00221346108982096$ 
Bednarz, R. \& Bednarz, S. W. (1995). Teaching geography skills. In W. Kemball (Ed.). Space and place: A geography manual for teachers. (p. 53-72). Washington, DC: Geographic Education Implementation Project (GENIP).

Board, C. (1978). Map reading tasks appropriate in experimental studies in cartographic communication. Cartographica: The International Journal for Geographic Information and Geovisualization, 15(1), 1-12. DOI: 10.3138 / AG15-V252-3726-W346

Brown, R. G. (1986). Map, globe, and graphing readiness activities: Developing universal thinking skills. The Social Studies, 77(6), 229-233. DOI: 10.1080/00377996.1986. 9957432

Buğdaycı, İ. \& Selvi, H. Z. (2018). The contribution to learning skills of maps designed for primary school pupils. Ömer Halisdemir University Journal of Engineering Sciences, $7(2), 672-684$.

Buğdaycı, İ. (2012). An evaluatıon about map use in elementary schools. (Unpublished doctoral thesis). Selçuk University Graduate School of Natural and Applied Sciences, Konya. Retrieved from: https://tez.yok.gov.tr

Büyüköztürk, Ş., Kılıç Çakmak, E., Akgün, Ö. E., Karadeniz, Ş. \& Demirel, F. (2012). Scientific research methods (Rev. Ed. 12th Edition). Ankara: Pegem Akademi.

Cendek, M. E. (2015). The opinions of social studies teachers related to development about student's reading maps. (Unpublished master thesis). Marmara University Institute of Educational Sciences, İstanbul. Retrieved from: https://tez.yok.gov.tr

Chang, C. Y. (2002). Does computer-assisted instruction + problem solving = improved science outcomes? A pioneer study. The Journal of Educational Research, 95(3), 143150.

Çarkungöz, E. \& Ediz. B. (2009). Meta analysis. Uludağ Univ. J. Fac. Vet. Med., 28(1), 33-37.

Çelikkaya, T. (2011). Transmission level of skills in the social studies curriculum: Theacher's opinions. Kastamonu Education Journal, 19(3), 969-990.

Çelikkaya, T., Yıldırım, T. \& Kürümlüoğlu, M. (2019). Ability hierarchies, reasons and recommendations of students and social studies teachers regardıng ability in social studies curriculum. Manas Journal of Social Studies, 8(1), 111-132.

*Daşdemir, İ. (2013). The effects of geographic informetion systems usage on students' acedemic achievement in social studes teaching. (Unpublished master thesis). Muğla Sitkı Koçman University Institute of Educational Sciences, Muğla. Retrieved from: https://tez.yok.gov.tr

Demiralp, N. (2006). The development of map and globe skills by the use of demonstration method in geography education. (Unpublished doctoral thesis). Gazi University Institute of Educational Sciences, Ankara. Retrieved from: https://tez.yok.gov.tr

Dijk, H. V., Schee, J. V. D., Trimp, H. \& Zijpp, T. V. D. (1994) Map skills and geographical knowledge. International Research in Geographical and Environmental Education, 3(1), 68-80. DOI: 10.1080/10382046.1994.9964928

Dikmen, M. \& Tuncer, M. (2018). A meta-analysis of effects of computer assisted education on students' academic achievement: A-10-year review of achievement effect. Turkish Journal of Computer and Mathematics Education, 9(1), 97-121.

Dinçer, S. (2014). Applied meta-analysis in educational sciences (1st Edition). Ankara: Pegem Akademi. 
Yalçınkaya, E., Karaca, A. (2021). Examination of studies aimed at developing map skills in ...

Dochy, F., Segers, M., Bossche P. V. D. \& Gijbels, D. (2003). Effects of problem-based learning: A meta-analysis. Learning and Instruction, 13(5), 533-568.

Doğanay, H. \& Sever, R. (2011). General and physical geography (10th Edition). Ankara: Pegem Akademi.

Drumheller, S. J. (1968). Conjure up a map: A crucial but much neglected skill. Journal of Geography, 67(3), 140-146. DOI: 10.1080/00221346808980914

Duman, B. \& Girgin, M. (2007). Views of education faculty students on map literacy. Eastern Geographical Review, 127, 185-202.

Duman, H. (2011). Using map in teaching of social studies and teachers' opinions about using map. (Unpublished master thesis). Uludağ University Institute of Educational Sciences, Bursa. Retrieved from: https://tez.yok.gov.tr

Duval, S. \& Tweedie, R. (2000) A nonparametric "trim and fill" method of accounting for publication bias in meta-analysis. Journal of the American Statistical Association, 95(449), 89-98. DOI: 10.1080/01621459.2000.10473905

Erol, H. (2019). Social studies preservice teachers' mapping skills. Kastamonu Education Journal, 27(2). 737-752. DOI: 10.24106/kefdergi.2710

Erol, H. (2020). 8th grade students' positioning skills on the map. Eurasian Journal of Educational Research, 88, 67-86.

Fletcher-Flinn, C. M. \& Gravatt, B. (1995). The efficacy of computer assisted instruction (CAI): A meta-analysis. J. Educatıonal Computıng Research, 12(3), 219-242.

Geography Education Standards Project [GESP]. (1994). Geography for life: National geography standards. Washington, DC: National Geographic Society. ISBN-0-79222775-1

Gerber, R. (1984). Factors affecting the competence and performance in map language for children at the concrete level of map-reasoning, Cartography, 13(3), 205-213. DOI: 10.1080/00690805.1984.10438268

Gilmartin, P. P. \& Patton, J. C. (1984). Comparing the sexes on spatial abilities: Map-use skills. Annals of the Association of American Geographers, 74(4), 605-619. DOI: 10.1111/j.1467-8306.1984.tb01477.x

Gökçe, N. (2015). Social studies in improving students' map skills: Teachers' opinions. Educational Sciences: Theory \& Practice, 15(5), 1345-1362.

Havelková, L. \& Hanus, M. (2019a). Research into map-analysis strategies: Theory- and data-driven approaches. Geografie, 124(2), 187-216.

Havelková, L. \& Hanus, M. (2019b). Map skills in education: a systematic review of terminology, methodology, and influencing factors. Review of International Geographical Education Online (RIGEO), 9(2), 361-401. Retrieved from: http://www.rigeo.org/vol9no2/Number2Summer/RIGE0-V9-N2-6.pdf

Herrmann, D. \& Pickle, L. W. (1996) A cognitive subtask model of statistical map reading. Visual Cognition, 3(2), 165-190. DOI: 10.1080/713756734

Higgins, J. P. T., Thompson, S. G., Deeks, J. J. \& Altman, D. G. (2003). Measuring inconsistency in meta-analyses. BMJ, 327, 557-560. 
Hirsch. P. L. \& Sandberg, E. H. (2013) Development of map construction skills in childhood. Journal of Cognition and Development, 14(3), 397-423, DOI: 10.1080/15248372.2012.669219

İncekara, S. \& Kantürk, G. (2010). The conception of maps among the teacher candidates of social sciences and their approaches to using maps. Marmara Geographical Journal, 21, 240-257.

İncekara, S. (2013). How do undergraduate geography students rate their map skills? Theory and practice. Hacettepe University Journal of Education, 28(1), 177-188.

İnel, Y. (2011). Developing skills of map scale using in teaching social studies. (Unpublished master thesis). Gazi University Institute of Educational Sciences, Ankara. Retrieved from: https://tez.yok.gov.tr

Johnson, D. W., Johnson, R. T. \& Stanne, M. B. (2000). Cooperative learning methods: A metaanalysis. Retrieved from: https://www.semanticscholar.org/paper/Cooperativelearning-methods\%3A-A-meta-analysis.-JohnsonJohnson/93e997fd0e883cf7cceb3b1b612096c27aa40f90?sort=relevance\&page $=2 \&$ pdf=true

Kablan, Z., Topan, B. \& Erkan, B. (2013). The effectiveness level of material use in classroom instruction: A meta-analysis study. Educational Sciences: Theory \& Practice, 13(3), 1638-1644.

Karadağ, E., İsci, S., Öztekin, S. \& Anar, S. (2016). The relationship between school climate and students' academic achievement: A meta-analysis study. Inönü University Journal of the Faculty of Education, 17(2), 107-122. DOI: 10.17679/iuefd.17294446

*Karatekin, K. (2006). The effect of teaching the subject of direction and finding methods according to multiple intelligence theory on students success at the 4th class of primary school. (Unpublished master thesis). Gazi University Institute of Educational Sciences, Ankara. Retrieved from: https://tez.yok.gov.tr

Kastens, K. A. \& Liben, L. S. (2010). Children's strategies and difficulties while using a map to record locations in an outdoor environment. International Research in Geographical and Environmental Education, 19(4), 315-340.

Koç, H. \& Çifçi, T. (2016). An investigation into map literacy levels of elementary school teacher candidates based on various variables. Marmara Geographical Review, 34, 920.

Koç, H. (2008). The effect of the gains at the program of geography teaching on skill levels of mapping of the students. (Unpublished doctoral thesis). Gazi University Institute of Educational Sciences, Ankara. Retrieved from: https://tez.yok.gov.tr

Koç, H. (2013). A study on determining the relation between the level of mapping skills and learning styles. Uşak University Journal of Social Sciences, 6(4), 17-32.

Koç, H., Aksoy, B. \& Çifçi, T. (2017). An examination of map literacy levels of students from various undergraduate programmes according to several variables: Cumhuriyet University sample. Erzincan University Education Journal, 19(3), 301-321. DOI: 10.17556/erziefd.331083

Kulik, C. L. C. \& Kulik, J. A. (1991). Effectiveness of computer-based instruction: An updated analysis. Computers in Human Behavior, 7, 75-94. 
Yalçınkaya, E., Karaca, A. (2021). Examination of studies aimed at developing map skills in ...

Kuşcu, Ö. (2011). Developing the position and coordinate determination skill in social sciences course. (Unpublished master thesis). Gazi University Institute of Educational Sciences, Ankara. Retrieved from: https://tez.yok.gov.tr

Larwin, K. \& Larwin, D. (2011). A meta-analysis examining the impact of computerassisted instruction on postsecondary statistics education: 40 years of research. Journal of Research on Technology in Education, 43(3), 253-278.

Lee, J. \& Bednarz, R. (2012). Components of spatial thinking: Evidence from a spatial thinking ability test. Journal of Geography, 111(1), 15-26. DOI: 10.1080 / 00221341.2011 .583262

Liebenberg, E. C. (1998). Teaching map use in a multicultural environment. South African Geographical Journal, 80(2), 111-117. DOI: 10.1080/03736245.1998.9713654

Long, J. (2001, February). An introduction to and generalization of the "fail-safe n". Paper presented at the Annual Meeting of the Southwest Educational Research Association, New Orleans, LA. Retrieved from: https://files.eric.ed.gov/fulltext/ED449210.pdf

Malik, T. (2015). Enhancing mapping skills - problems and possibilities. Indian Journal of Applied Research, 5(4), 183-185.

McClure, R. W. (1992). A conceptual model for map skills curriculum development based upon a cognitive field theory philosophy. (Unpublished doctoral thesis). Oklahoma State University, Oklahoma.

Miles, M. B. \& Huberman, A. M. (1994). Qualitative data analysis: An expanded sourcebook (2nd Ed.). Thousand Oaks: Sage Publications.

MoNE [Ministry of National Education] (2018). Secondary School Geography Curriculum (9th, 10th, 11th and 12th Grades). Retrieved from: http://mufredat.meb.gov.tr /Dosyalar/2018120203724482-Cografya\%20dop\%20pdf.pdf

Muehrecke, P. C. (1981). Whatever happened to geographic cartography?. Professional Geographer, 33(4), 397-405. DOI: 10.1111 / j.0033-0124.1981.00397.x

National Geographic. (n.d). Geographic skills index. Retrieved from: https://www.nationalgeographic.org /geographic-skills/

Nuñez, J. J. R (2002, August). Teaching maps in Portuguese and Hungarian elementary schools: A study. Paper presented at the Cartography and Children and Caryografia Para Escolares, Diamantina, Brazil. Retrieved from: http://ishm.elte.hu/ccc/10years/ ea/jesus2.pdf

Öğ̈̈tveren, M. (2014). The influence of Google Earth software on the success of teaching geographical topics for the 6th grade students. (Unpublished master thesis). Giresun University Institute of Social Sciences, Giresun. Retrieved from: https://tez.yok.gov.tr

Özcan, F. (2015). Social studies pre-service teachers' self-efficacy and achievement levels on map reading. (Unpublished master thesis). Aksaray University Institute of Social Sciences, Aksaray. Retrieved from: https://tez.yok.gov.tr

Rautenbach, V., Coetzee, S. \& Çöltekin, A. (2016). Development and evaluation of a specialized task taxonomy for spatial planning: A map literacy experiment with topographic maps. ISPRS Journal of Photogrammetry and Remote Sensing, 127, 1-11.

Rosenthal, R. (1979). The "file drawer problem" and tolerance for null results. Psychological Bulletin, 86(3), 638-641. 
Safaraliyeva, N., Al Hosani N. \& Nuñez, J. J. R. (2019) Teaching basic map concepts in three countries: Azerbaijan, Hungary and United Arab Emirates. International Journal of Cartography, 5(2-3), 285-303. DOI: 10.1080/23729333.2019.1614308

Sezer, A. \& İnel, Y. (2017). The effect of the usage of instructional materials on student achievement in teaching geography: A meta-analytic study. Journal of History Culture and Art Research, 6(3), 473-491. doi:http://dx.doi.org/10.7596/taksad.v6i3.913

Shachar, M. \& Neumann, Y. (2003). Differences between traditional and distance education academic performances: A meta-analytic approach. International Review of Research in Open and Distance Learning, 4(2), 1-20.

Smith, F. G. (2002) Thinking skills: The question of generality. Journal of Curriculum Studies, 34(6), 659-678. DOI: 10.1080/00220270110119905

Sönmez, Ö. F. (2010). Map skills in primary school social studies education. (Unpublished doctoral thesis). Gazi University Institute of Educational Sciences, Ankara. Retrieved from: https://tez.yok.gov.tr

Sönmez, Ö. F. (2019). Map literacy. In B. Aksoy, B. Akbaba \& B. Kılcan (Eds.). Skill training in Social Studies. (p. 219-232). Ankara: Pegem Akademi.

*Şendil, S. (2011). The effect of the use of 3-d plastic relief map on learning in primary education 7 th grade social sciences lesson. (Unpublished master thesis). Gazi University Institute of Educational Sciences, Ankara. Retrieved from: https://tez.yok.gov.tr

*Şimşek, N. (2007). The influence of applications and activities based on GIS in the teaching of social studies on student's succes and attitudes to the socail studies. (Unpublished doctoral thesis). Gazi University Institute of Educational Sciences, Ankara. Retrieved from: https://tez.yok.gov.tr

Tabanl, C. B. (2014). The effect of using gis in seventh grade social studies class on students' academical success. (Unpublished master thesis). Giresun University Institute of Social Sciences, Giresun. Retrieved from: https://tez.yok.gov.tr

Taşkıran, C., Baş, K. \& Bulut, B. (2016). The level of acquired social studies specific skills. Journal of Social Sciences, 6(11), 1-19.

Thalheimer, W. \& Cook, S. (2002). How to calculate effect size from published research: A simplified methodology. Retrieved from: http://www.bwgriffin.com/gsu/courses /edur9131/content/Effect_Sizes_pdf5.pdf

Turan, R. (2018). A general evaluation on 2017 primary and middle school social studies curriculum. Dialectology National Journal of Social Sciences, 19, 295-328.

Turkish Language Institution Dictionaries [TDK]. (n.d). Current Turkish dictionary. Retrieved from: https://sozluk.gov.tr/

Tutal, Ö. (2019). The effect of active learning approach on students' academic achievement, attitudes towards the course and retention: A meta-analysis study. (Unpublished doctoral thesis). Dicle University Institute of Educational Sciences, Diyarbakır. Retrieved from: https://tez.yok.gov.tr

*Türel, A. (2019). The effect of using google earth towards students' avhievement and attiudes in social studies course of seven graders. (Unpublished master thesis). Akdeniz University Institute of Educational Sciences, Antalya. Retrieved from: https://tez.yok.gov.tr 
*Ünal, B. (2012). The impact of the education of the social studies which is geographic information systems assisted on the students' success and the attitude. (Unpublished master thesis). Akdeniz University Institute of Social Sciences, Antalya. Retrieved from: https://tez.yok.gov.tr

*Üzümcü, N. 0. (2007). The acquisition of the ability of reading map using the technic of active learning in the 6th grade of primary school. (Unpublished master thesis). Gazi University Institute of Educational Sciences, Ankara. Retrieved from: https://tez.yok.gov.tr

Vernon, D. T. A. \& Blake, R. L. (1993). Does problem-based learning work? A meta-analysis of evaluative research. Academic Medicine, 68(7), 550-563.

Yıldırım, İ., Çırak Kurt, S. \& Şen, S. (2019). The effect of teaching "learning strategies" on academic achievement: A meta-analysis study. Eurasian Journal of Educational Research, 79, 87-114. DOI: 10.14689/ejer.2019.79.5

Yıldırım, N. (2015). Meta analysis. In M. Metin (Ed.). Scientific research methods in education. (p. 138-158). Ankara: Pegem Akademi.

(Resources marked with the symbol "*" are the resources included in the meta-analysis research.)

\section{Biographical Statements}

Elvan YALÇINKAYA is an associate professor in the Department of Turkish and Social Sciences Education at the University of Erciyes. His research interests are social studies education, geography education and environmental education.

Ayten KARACA is a $\mathrm{PhD}$ student at Niğde Ömer Halisdemir University Institute of Educational Sciences. Her areas of interest include social studies education, geography education and Lesson Study Model in development of teaching profession. 